J. Japan. Soc. Hort. Sci. 50(4) : 475-480. 1982.

\title{
Effects of Nitrogen Form on Growth of Muskmelons
}

\author{
Masao Masui, Akira Nukaya and Akira Ishida \\ College of Agriculture, Shizuoka University, Ohya, Shizuoka 422
}

\begin{abstract}
Summary
Muskmelons (Cucumis melo L.) were grown in sand with $7 \mathrm{~N}$ form treatments $\left(\mathrm{NO}_{3}: \mathrm{NH}_{4} ; 10: 0,8: 2,6: 4,5: 5,4: 6,2: 8\right.$ and $\left.0: 10\right)$ supplied daily at a concentration of $90 \mathrm{ppm}$. A total of 78 liters of treatment solution was applied per plant throughout the experiment. The higher $\mathrm{NH}_{4}$ ratios caused plant growth and fruit fresh weight to decrease, while fruit soluble solids remained slightly higher. With increasing $\mathrm{NH}_{4}$ ratios $\mathrm{N}$ in leaves increased. $\mathrm{NO}_{3}-\mathrm{N}$ and $\mathrm{NH}_{4}-\mathrm{N}$ in the plant parts and medium (sand) reflected the form of $\mathrm{N}$ that was supplied. $\mathrm{N}$ uptake by plants at all $\mathrm{NH}_{4}$ ratios was greatest at $5,137 \mathrm{mg}$ per plant. With increasing $\mathrm{NH}_{4}$ ratios $\mathrm{NH}_{4}-\mathrm{N}$ in soil solution increased, while $\mathrm{NO}_{3}-\mathrm{N}$ and $\mathrm{Na}$, and $\mathrm{pH}$ and $\mathrm{EC}$ values tended to decrease.
\end{abstract}

\section{Introduction}

Greenhouse muskmelon growers in Shizuoka Prefecture use mainly rapeseed cake and fish cake to supply nitrogen (N) fertilizer in a slowly available form for the production of high quality fruit. In general, rapidly available $\mathrm{N}$ in large amounts tends to produce poor quality fruit $(8,9)$. However, when analized for $\mathrm{NO}_{3}-\mathrm{N}$ and $\mathrm{NH}_{4}-\mathrm{N}$ in soils producing high quality fruit, amounts of these $\mathrm{N}$ forms tended to vary with the kind of soils, the number of crops per year, fertilization, cultural practices etc. $(8,9,10)$. Thus a question arises as to which muskmelons prefer $\mathrm{NO}_{3}-\mathrm{N}$ or $\mathrm{NH}_{4}-\mathrm{N}$ per se. The objective of this study was to determine the growth of muskmelons grown in sand applied with nutrient solution containing different ratios of $\mathrm{NO}_{3}: \mathrm{NH}_{4}$.

\section{Materials and Methods}

Thirty-two uniform seedlings of muskmelons (Cucumis melo L. cv. Earl's Favourite Fall No.1) were used. Treatments consisted of 7 plots receiving $\mathrm{NO}_{3}: \mathrm{NH}_{4}$ ratios as $10: 0,8: 2,6: 4,5: 5,4: 6,2: 8$ and $0: 10$. Control plants were grown in soil fertilized with $7 \mathrm{~g} \mathrm{~N}$ per plant from rapeseed

Received for publication October 9, 1981 cake. Thus there were 8 plots, each having 4 replications. On Sept. 14, 1978, seedlings with 2.5 to 3 leaves were planted in $40 \times 40$ $\times 20 \mathrm{~cm}$ boxes filled with 19 liters of Tenryu River sand which was classified into Loamy coarse sand (LS). This LS refers to sand for short thereafter. The bottom of boxes was filled with $2 \mathrm{~kg}$ rice straw to maintain good aeration. The muskmelons were grown in a three-quarter greenhouse kept at $20^{\circ} \mathrm{C}$ to $30^{\circ} \mathrm{C}$ during the day and $18^{\circ} \mathrm{C}$ to $20^{\circ} \mathrm{C}$ at night. The $\mathrm{N}$ source of $\mathrm{NO}_{3}$ and $\mathrm{NH}_{4}$ was $\mathrm{NaNO}_{3}$ and $\left(\mathrm{NH}_{4}\right)_{2} \mathrm{SO}_{4}$, respectively. The composition of the nutrient solution except for $\mathrm{N}$ was as follows: $\mathrm{Na}_{2} \mathrm{HPO}_{4} \cdot 12 \mathrm{H}_{2} \mathrm{O}(1 \mathrm{mM})$, $\mathrm{K}_{2} \mathrm{SO}_{4}(3 \mathrm{mM}), \quad \mathrm{CaCl}_{2} \cdot 2 \mathrm{H}_{2} \mathrm{O}(4 \mathrm{mM}), \quad \mathrm{Mg}-$ $\mathrm{SO}_{4} \cdot 7 \mathrm{H}_{2} \mathrm{O}(2 \mathrm{mM}), \quad \mathrm{Fe}$ from Fe-EDTA (1 $\mathrm{ppm}), \mathrm{Mn}$ from $\mathrm{MnSO}_{4}(0.5 \mathrm{ppm}), \mathrm{B}$ from $\mathrm{H}_{3} \mathrm{BO}_{3} \quad(0.5 \mathrm{ppm}), \quad \mathrm{Zn}$ from $\mathrm{ZnSO}_{4} \cdot 7 \mathrm{H}_{2} \mathrm{O}$ $(0.05 \mathrm{ppm}), \mathrm{Cu}$ from $\mathrm{CuSO}_{4} \cdot 5 \mathrm{H}_{2} \mathrm{O}(0.02$ ppm) and $\mathrm{Mo}$ from $\mathrm{Na}_{2} \mathrm{MoO}_{4} \cdot 2 \mathrm{H}_{2} \mathrm{O} \quad(0.05$ $\mathrm{ppm})$. Nutrient solutions containing $90 \mathrm{ppm}$ $\mathrm{N}\left(\mathrm{NO}_{3}+\mathrm{NH}_{4}\right)$ at $\mathrm{pH} 6.0$ were applied 1 or 2 times each day in equal quantities of 0.75 liters to each box whether it was cloudy or sunny. No solutions were applied on rainy days. A total of 78 liters of solution was applied per plant throughout the experiment. The control plot was basically fertilized with $4 \mathrm{~g} \mathrm{~N}$ from rapeseed cake, $10 \mathrm{~g} \mathrm{P}_{2} \mathrm{O}_{5}$ from calcium superphosphate, $8 \mathrm{~g} \mathrm{~K}_{2} \mathrm{O}$ from $\mathrm{K}_{2} \mathrm{SO}_{4}$ 
and $20 \mathrm{~g} \mathrm{CaO}$ from $\mathrm{Ca}(\mathrm{OH})_{2}$. In addition, $1.5 \mathrm{~g} \mathrm{~N}$ from rapeseed cake were applied on Oct. 4 and Oct. 27, 1978. Control plants were watered at the same time the treated plants received nutrient solutions. Total tissue $\mathrm{N}$ determination followed the method used by Peterson and Chesters(13). Tissue $\mathrm{NO}_{3}-\mathrm{N}$ and $\mathrm{NH}_{4}-\mathrm{N}$ were determined electrometically, using a distilled water extract of dried, ground plant tissue. Tissue $\mathrm{K}, \mathrm{Na}$, $\mathrm{Ca}$ and $\mathrm{Mg}$ were determined by an atomic absorption photometer, and $\mathrm{P}$ by an ammonium molybdate procedure. Samples of sand mediums were taken on the 29 th, 57 th and 83 rd day after planting, and air-dried, and $\mathrm{NH}_{4}-\mathrm{N}$ and $\mathrm{NO}_{3}-\mathrm{N}$ were determined. Also the chemical properties of the soil solution were determined at the end of the experiment on the extract centrifugally taken at $\mathrm{pF} 0$ to 3.8. The resulting data were subjected to the analysis of variance, and differences among means were tested by Duncan's method.

\section{Results}

1. Plant and fruit growth (Table 1).

Dry weight of the leaves, stem and whole plant was greatest at $\mathrm{NO}_{3}: \mathrm{NH}_{4}=8: 2$, and that of leaves, stem and roots was less at $2: 8$, and $0: 10$. Dry weight of the roots was greater at $\mathrm{NO}_{3}: \mathrm{NH}_{4}=6: 4,5: 5$, and $4: 6$, while less at $10: 0$, and $2: 8$. Fruit fresh weight tended to decrease with de creasing ratios of $\mathrm{NO}_{3}: \mathrm{NH}_{4}$ except for $\mathrm{NO}_{3}: \mathrm{NH}_{4}=8: 2$. Fruit soluble solids were slightly greater at higher $\mathrm{NH}_{4}$ ratios. Fruit external appearance such as shape, net and rind color, and internal quality such as flesh texture and color, except for soluble solids, were not affected by treatments. The control fruit fresh weight was slightly greater, while soluble solids were slightly lower.

2. Elemental content in leaves (Table 2).

With decreasing ratios of $\mathrm{NO}_{3}: \mathrm{NH}_{4}, \mathrm{~N}$ tended to increase, while $\mathrm{P}, \mathrm{Na}, \mathrm{Ca}$ and $\mathrm{Mg}$ tended to decrease. The control $\mathrm{Ca}$ was greatest, while $\mathrm{N}, \mathrm{K}$ and $\mathrm{Na}$ was least.

3. $\mathrm{NO}_{3}-\mathrm{N}$ and $\mathrm{NH}_{4}-\mathrm{N}$ content in plant parts, and $N$ plant uptake (Table 3).

$\mathrm{NO}_{3}-\mathrm{N}$ in plant parts decreased with decreasing ratios of $\mathrm{NO}_{3}: \mathrm{NH}_{4}$. At the $\mathrm{NO}_{3}$ : $\mathrm{NH}_{4}=10: 0 \mathrm{NO}_{3}-\mathrm{N}$ was highest in the stem followed by the roots and then the leaves. The control $\mathrm{NO}_{3}-\mathrm{N}$ was lower in the stem. In leaves $\mathrm{NH}_{4}-\mathrm{N}$ was lower than $\mathrm{NO}_{3}-\mathrm{N}$, but was higher at $\mathrm{NO}_{3}: \mathrm{NH}_{4}=4: 6,2: 8$, and $0: 10$ than the others. $\mathrm{NH}_{4}-\mathrm{N}$ in the roots tended to increase with decreasing ratios of $\mathrm{NO}_{3}: \mathrm{NH}_{4}$. The $\mathrm{N}$ plant uptake (total of leaves, stem, roots and fruit) was greatest at all $\mathrm{NH}_{4}$ ratios showing $5,137 \mathrm{mg}$ per plant.

4. $\mathrm{NO}_{3}-\mathrm{N}$ and $\mathrm{NH}_{4}-\mathrm{N}$ content in sand during growing period (Table 4).

$\mathrm{NO}_{3}-\mathrm{N}$ in sand tended to increase with increasing ratios of $\mathrm{NO}_{3}: \mathrm{NH}_{4}$, and tended to increase with time at each ratio of $\mathrm{NO}_{3}: \mathrm{NH}_{4} \cdot \mathrm{NH}_{4}-\mathrm{N}$ in sand tended to increase with decreasing ratios of $\mathrm{NO}_{3}: \mathrm{NH}_{4}$ with increasing time. The control $\mathrm{NH}_{4}-\mathrm{N}$ was as low as $4.2 \mathrm{ppm}$ on Dec. 6 .

5. Chemical properties of soil solution

Table 1. Effect of nitrogen form on the growth of muskmelons in sand culture.

\begin{tabular}{|c|c|c|c|c|c|c|c|}
\hline \multirow{2}{*}{$\mathrm{NO}_{3}: \mathrm{NH}_{4}$} & \multirow{2}{*}{$\begin{array}{l}\text { Plant height } \\
\text { at harvest }(\mathrm{cm})\end{array}$} & \multirow{2}{*}{$\begin{array}{l}\text { Leaf dry } \\
\text { wt }(g)\end{array}$} & \multirow{2}{*}{$\begin{array}{l}\text { Stem dry } \\
\text { wt }(\mathrm{g})\end{array}$} & \multirow{2}{*}{$\begin{array}{l}\text { Root dry } \\
\text { wt }(g)\end{array}$} & \multirow{2}{*}{$\begin{array}{l}\text { Whole plant } \\
\text { dry wt (g) }\end{array}$} & \multicolumn{2}{|c|}{ Fruit } \\
\hline & & & & & & $\begin{array}{c}\text { Fresh wt } \\
(\mathrm{g})\end{array}$ & $\begin{array}{l}\text { Soluble } \\
\text { solids }(\%)\end{array}$ \\
\hline $10: 0$ & $116^{a^{2}}$ & $64.9^{a b}$ & 19. $0^{\mathrm{ab}}$ & $2.4^{\mathrm{b}}$ & $199^{a b c}$ & $1121^{\mathrm{a}}$ & $14.1^{\mathrm{c}}$ \\
\hline $8: 2$ & $116^{a}$ & $70.2^{\mathrm{a}}$ & $21.0^{\mathrm{a}}$ & $4.3^{a b}$ & $213^{\mathbf{a}}$ & $936^{b c}$ & $14.4^{\mathrm{bc}}$ \\
\hline $6: 4$ & $120^{\mathrm{a}}$ & $58.8^{\mathrm{ab}}$ & 18. $4^{\mathrm{abc}}$ & $5.5^{\mathrm{a}}$ & $207^{a b}$ & $1030^{\mathrm{ab}}$ & 15. $0^{\mathrm{ab}}$ \\
\hline $5: 5$ & $118^{\mathrm{a}}$ & $64.5^{\mathrm{ab}}$ & $19.3^{a b}$ & $5.4^{\mathrm{a}}$ & $205^{a b}$ & $923^{b c}$ & $14.9^{\mathrm{ab}}$ \\
\hline $4: 6$ & $112^{\mathrm{a}}$ & $55.1^{\mathrm{ab}}$ & 16. $6^{\mathrm{bcd}}$ & $5.6^{\mathrm{a}}$ & $186^{\mathrm{bcd}}$ & $907^{\mathrm{bc}}$ & $15.6^{\mathbf{a}}$ \\
\hline $2: 8$ & $111^{\mathrm{a}}$ & $47.6^{\mathrm{b}}$ & $14.0^{\mathrm{d}}$ & $2.5^{\mathrm{b}}$ & $175^{\mathrm{cd}}$ & $910^{b c}$ & $15.5^{\mathrm{a}}$ \\
\hline $0: 10$ & $112^{\mathrm{a}}$ & $50.7^{\mathrm{ab}}$ & $14.8^{\mathrm{cd}}$ & 3. $2^{\mathrm{ab}}$ & $168^{d}$ & $832^{c}$ & $15.7^{a}$ \\
\hline $\mathrm{Rs}_{\mathrm{s}}^{\mathrm{y}}$ & 114 & 53.0 & 18.8 & 2.3 & 209 & 1195 & 14.3 \\
\hline
\end{tabular}

${ }^{2}$ Mean separation in columns by Duncan's multiple range test, $5 \%$ level.

${ }^{y}$ Rapeseed cake. 
Table 2. Effect of nitrogen form on the elemental content of muskmelon leaves grown in sand culture ( $\%$ of dry wt).

\begin{tabular}{c|l|l|l|l|l|l}
\hline \hline $\mathrm{NO}_{3}: \mathrm{NH}_{4}$ & $\mathrm{~N}$ & $\mathrm{P}$ & $\mathrm{K}$ & $\mathrm{Na}$ & $\mathrm{Ca}$ & $\mathrm{Mg}$ \\
\hline $10: 0$ & $2.98^{\mathrm{c}}$ & $0.65^{\mathrm{a}}$ & $2.49^{\mathrm{b}}$ & $0.27^{\mathrm{a}}$ & $6.75^{\mathrm{a}}$ & $1.69^{\mathrm{a}}$ \\
$8: 2$ & $3.11^{\mathrm{c}}$ & $0.56^{\mathrm{b}}$ & $2.97^{\mathrm{ab}}$ & $0.20^{\mathrm{b}}$ & $5.20^{\mathrm{b}}$ & $1.26^{\mathrm{b}}$ \\
$6: 4$ & $3.54^{\mathrm{bc}}$ & $0.57^{\mathrm{b}}$ & $3.02^{\mathrm{ab}}$ & $0.20^{\mathrm{b}}$ & $4.24^{\mathrm{c}}$ & $1.11^{\mathrm{c}}$ \\
$5: 5$ & $3.35^{\mathrm{bc}}$ & $0.49^{\mathrm{c}}$ & $3.26^{\mathrm{a}}$ & $0.16^{\mathrm{b}}$ & $3.86^{\mathrm{c}}$ & $1.06^{\mathrm{c}}$ \\
$4: 6$ & $3.33^{\mathrm{bc}}$ & $0.49^{\mathrm{c}}$ & $3.26^{\mathrm{a}}$ & $0.18^{\mathrm{b}}$ & $3.98^{\mathrm{c}}$ & $1.11^{\mathrm{c}}$ \\
$2: 8$ & $3.85^{\mathrm{ab}}$ & $0.46^{\mathrm{c}}$ & $3.08^{\mathrm{ab}}$ & $0.11^{\mathrm{c}}$ & $3.48^{\mathrm{cd}}$ & $0.87^{\mathrm{d}}$ \\
$0: 10$ & $4.48^{\mathrm{a}}$ & $0.41^{\mathrm{d}}$ & $3.05^{\mathrm{ab}}$ & $0.10^{\mathrm{c}}$ & $3.31^{\mathrm{d}}$ & $0.88^{\mathrm{d}}$ \\
\hline $\mathrm{Rs} \mathrm{C}^{\mathrm{y}}$ & 2.08 & 0.44 & 2.16 & 0.07 & 7.15 & 0.73 \\
\hline
\end{tabular}

${ }^{z, y}$ Same as Table 1.

Table 3. Effect of nitrogen form on the nitrate and ammonium content of plant parts and $\mathrm{N}$ amount taken up by muskmelon plants grown in sand culture.

\begin{tabular}{|c|c|c|c|c|c|c|c|}
\hline \multirow{2}{*}{$\mathrm{NO}_{3}: \mathrm{NH}_{4}$} & \multicolumn{3}{|c|}{$\mathrm{NO}_{3}-\mathrm{N}$ (ppm of dry wt) } & \multicolumn{3}{|c|}{$\mathrm{NH}_{4}-\mathrm{N}(\mathrm{ppm}$ of dry wt) } & \multirow{2}{*}{$\begin{array}{l}N \text { taken up } \\
(\mathrm{mg} / \mathrm{plan} \mathrm{t})\end{array}$} \\
\hline & Leaves & Stem & Roots & Leaves & Stem & Roots & \\
\hline $10: 0$ & $773^{a^{z}}$ & $3423^{a}$ & $1061^{\mathbf{a}}$ & $36^{\mathrm{b}}$ & $284^{\mathrm{a}}$ & $267^{\mathrm{c}}$ & 4446 \\
\hline $8: 2$ & $633^{a b}$ & $2755^{a}$ & $661^{\mathbf{b}}$ & $33^{b}$ & $255^{\mathrm{a}}$ & $275^{c}$ & 4470 \\
\hline $6: 4$ & $645^{\mathrm{ab}}$ & $1605^{b}$ & $385^{c}$ & $35^{b}$ & $371^{\mathrm{a}}$ & $315^{\mathrm{b}}$ & 4848 \\
\hline $5: 5$ & $609^{a b}$ & $818^{\mathrm{c}}$ & $222^{\mathrm{d}}$ & $36^{\mathrm{b}}$ & $308^{\mathrm{a}}$ & $308^{b}$ & 4557 \\
\hline $4: 6$ & $481^{\mathrm{bc}}$ & $583^{c}$ & $123^{\mathrm{e}}$ & $47^{\mathrm{ab}}$ & $391^{\mathbf{a}}$ & $332^{\mathrm{ab}}$ & 4425 \\
\hline $2: 8$ & $306^{c}$ & $260^{c}$ & $44^{\mathrm{f}}$ & $55^{\mathrm{a}}$ & $331^{\mathrm{a}}$ & $354^{\mathrm{a}}$ & 4412 \\
\hline $0: 10$ & $337^{\mathrm{c}}$ & $178^{\mathrm{c}}$ & $31^{f}$ & $54^{\mathrm{a}}$ & $306^{\mathbf{a}}$ & $343^{\mathrm{a}}$ & 5137 \\
\hline $\mathrm{Rs} \mathrm{C}^{\mathrm{y}}$ & 539 & 213 & 218 & 22 & 311 & 321 & 2949 \\
\hline
\end{tabular}

${ }^{z, y}$ Same as Table 1. ${ }^{x}$ Not subjected to statistical analysis.

Table 4. Nitrate and ammonium content of sand during growing period (ppm of dry sand).

\begin{tabular}{|c|c|c|c|c|c|c|}
\hline \multirow{2}{*}{$\mathrm{NO}_{3}: \mathrm{NH}_{4}$} & \multicolumn{3}{|c|}{$\mathrm{NO}_{3}-\mathrm{N}$} & \multicolumn{3}{|c|}{$\mathrm{NH}_{4}-\mathrm{N}$} \\
\hline & Oct. 13 & Nov. 11 & Dec. 6 & Oct. 13 & Nov. 11 & Dec. 6 \\
\hline $10: 0$ & 4. $4^{\mathrm{a}^{\mathrm{z}}}$ & $7.5^{\mathrm{ab}}$ & $22.0^{\mathbf{a}}$ & $1.8^{\mathrm{d}}$ & $1.4^{\mathrm{e}}$ & 2. $3^{\mathrm{g}}$ \\
\hline $8: 2$ & $2.9^{\mathbf{b}}$ & $8.7^{\mathrm{a}}$ & $14.4^{\mathrm{b}}$ & $1.7^{\mathrm{d}}$ & $1.4^{\mathrm{e}}$ & $6.7^{\mathrm{f}}$ \\
\hline $6: 4$ & 3. $0^{\mathrm{ab}}$ & $6.6^{\mathrm{b}}$ & $9.3^{\mathrm{c}}$ & $1.5^{\mathrm{d}}$ & $1.9^{\mathrm{de}}$ & $12.8^{\mathrm{e}}$ \\
\hline $5: 5$ & $2.6^{\mathrm{b}}$ & $4.3^{c}$ & $7.4^{\mathrm{cd}}$ & 1. $6^{\mathrm{d}}$ & $2.1^{\mathrm{d}}$ & 16. $7^{d}$ \\
\hline $4: 6$ & 3. $2^{\mathrm{ab}}$ & $4.4^{c}$ & $6.1^{\mathrm{de}}$ & 3. $0^{c}$ & $3.3^{\mathrm{c}}$ & $20.0^{c}$ \\
\hline $2: 8$ & $2.3^{\mathbf{b}}$ & $2.8^{\mathrm{e}}$ & $4.2^{\mathrm{ef}}$ & $5.4^{\mathrm{b}}$ & $5.7^{b}$ & $31.3^{b}$ \\
\hline $0: 10$ & $1.8^{\mathrm{b}}$ & $1.0^{d}$ & $2.0^{\mathrm{f}}$ & $6.3^{a}$ & $7.7^{\mathrm{a}}$ & $35.7^{\mathrm{a}}$ \\
\hline $\operatorname{Rs} C^{y}$ & 51.7 & 7.6 & 21.8 & 4.5 & 4.0 & 4.2 \\
\hline
\end{tabular}

${ }^{\text {, }}{ }^{\mathrm{S}}$ Same as Table 1.

(Table 5).

With increasing ratios of $\mathrm{NO}_{3}: \mathrm{NH}_{4}, \mathrm{NO}_{3}$ $\mathrm{N}$ and $\mathrm{Na}$, and $\mathrm{pH}$ and $\mathrm{EC}$ values increased, while $\mathrm{NH}_{4}-\mathrm{N}$ decreased. $\mathrm{P}$ was higher at $\mathrm{NO}_{3}: \mathrm{NH}_{4}=10: 0$, and $\mathrm{K}, \mathrm{Ca}$ and $\mathrm{Mg}$ was lower at $\mathrm{NO}_{3}: \mathrm{NH}_{4}=0: 10$. The control pH was as high as 6.73 , while $\mathrm{NH}_{4}-\mathrm{N}, \mathrm{K}, \mathrm{Na}$ and $\mathrm{Mg}$ were markedly low.

\section{Discussion}

This experiment showed that higher $\mathrm{NH}_{4}$ ratios reduce plant growth and fruit weight, increase fruit soluble solids, decrease $\mathrm{Ca}$ and $\mathrm{Mg}$ in leaves, and increase $\mathrm{N}$ in leaves of muskmelons in sand culture. Similar results were reported for some vegetable crops $(1,2$, $3,4,5,6,7,12,15)$. The reason of reduced 
Table 5. Chemical properties of soil solution $(\mathrm{pF}=0 \sim 3.8)$ at the end of experiment.

\begin{tabular}{|c|c|c|c|c|c|c|c|c|c|}
\hline $\mathrm{NO}_{3}: \mathrm{NH}_{4}$ & $\begin{array}{c}\mathrm{NO}_{3}-\mathrm{N} \\
(\mathrm{ppm})\end{array}$ & $\begin{array}{r}\mathrm{NH}_{4}-\mathrm{N} \\
(\mathrm{ppm})\end{array}$ & $\begin{array}{c}\mathrm{P} \\
(\mathrm{ppm})\end{array}$ & $\underset{(\mathrm{me} / l)}{\mathrm{K}}$ & $\underset{(\mathrm{me} / l)}{\mathrm{Na}}$ & $\begin{array}{c}\mathrm{Ca} \\
(\mathrm{me} / \mathrm{l})\end{array}$ & $\underset{(\mathrm{me} / l)}{\mathrm{Mg}}$ & $\mathrm{pH}$ & $\underset{(\mathrm{m} \mho / \mathrm{cm})}{\mathrm{EC}}$ \\
\hline $10: 0$ & $108^{a^{z}}$ & $5^{8}$ & $9.7^{a}$ & $10.3^{a}$ & $34.7^{\mathrm{a}}$ & $14.1^{\mathrm{ab}}$ & $13.0^{\mathrm{ab}}$ & $6.68^{a}$ & $7.18^{a}$ \\
\hline $8: 2$ & $86^{b}$ & $14^{\mathrm{f}}$ & $4.3^{b}$ & 9. $7^{\mathrm{ab}}$ & $23.4^{\mathrm{b}}$ & 13. $2^{a b c}$ & $11.5^{\mathrm{ab}}$ & $6.00^{\mathrm{b}}$ & $6.88^{\mathrm{ab}}$ \\
\hline $6: 4$ & $55^{c}$ & $29^{\mathbf{e}}$ & $3.4^{\mathrm{b}}$ & $10.3^{a}$ & $21.6^{b}$ & $14.5^{\mathrm{ab}}$ & $13.9^{\mathrm{a}}$ & $5.20^{c}$ & $6.96^{\mathrm{ab}}$ \\
\hline $5: 5$ & $37^{\mathrm{d}}$ & $38^{d}$ & $2.8^{\mathrm{b}}$ & $9.9^{\mathrm{ab}}$ & 19. $1^{b c}$ & $14.7^{\mathrm{a}}$ & $13.8^{\mathrm{ab}}$ & $5.00^{\mathrm{cd}}$ & $6.06^{\mathrm{bc}}$ \\
\hline $4: 6$ & $35^{\mathrm{de}}$ & $48^{\mathrm{c}}$ & $2.7^{\mathrm{b}}$ & $9.7^{\mathrm{ab}}$ & $16.1^{\mathrm{c}}$ & $15.1^{\mathrm{a}}$ & $14.3^{\mathrm{a}}$ & 4. $80^{\mathrm{de}}$ & $5.89^{\mathrm{cd}}$ \\
\hline $2: 8$ & $24^{\mathrm{e}}$ & $73^{\mathrm{b}}$ & $3.1^{\mathrm{b}}$ & $7.5^{b c}$ & $10.5^{d}$ & $12.4^{\mathrm{bc}}$ & 12. $0^{\mathrm{ab}}$ & 4. $59^{\mathrm{ef}}$ & $4.93^{\mathrm{de}}$ \\
\hline $0: 10$ & $8^{e}$ & $86^{a}$ & $3.7^{\mathrm{b}}$ & $5.7^{\mathrm{c}}$ & $5.6^{e}$ & $11.8^{c}$ & $10.6^{\mathrm{b}}$ & $4.50^{\mathrm{f}}$ & $4.32^{\mathrm{e}}$ \\
\hline $\operatorname{Rs} C^{y}$ & 98 & 4 & 5.7 & 3.1 & 6.5 & 27.7 & 8.1 & 6.73 & 4.33 \\
\hline
\end{tabular}

${ }^{z, y}$ Same as Table 1.

plant growth and fruit weight (Table 1) may be due to excess $\mathrm{NH}_{4}$ uptake by plant, depressed $\mathrm{Ca}$ absorption by plants, a lowering of medium $\mathrm{pH}$ etc. In this experiment $\mathrm{NH}_{4}$ injury was not found on leaves. However, $\mathrm{NH}_{4}-\mathrm{N}$ content in sand and soil solution seemed to be high enough to reduce plant growth and fruit weight as showing 35.7 and $86 \mathrm{ppm}$ at $\mathrm{NO}_{3}: \mathrm{NH}_{4}=0: 10$, respectively. Fruit soluble solids were slightly greater at higher $\mathrm{NH}_{4}$ ratios. This seems to be due to fruit weight because small fruits have generally higher soluble solids under greenhouse cultivation. In general, higher $\mathrm{NH}_{4}$ supply promotes protein synthesis in plants. However, vigorous protein synthesis of ten reduces plant growth due to an excess $\mathrm{NH}_{4}$ when the carbohydrate is deficient within plants. As shown in Table 2, $\mathrm{N}$ content in leaves increased with increasing $\mathrm{NH}_{4}$ ratios. In comparing these results to another study (11), more than $3.5 \% \mathrm{~N}$ in leaves seem to be high for plant growth. Thus the ratio of $\mathrm{NO}_{3}: \mathrm{NH}_{4}$ for optimum plant growth seems to be $10: 0$ or $8: 2$ judging only from the $\mathrm{N}$ content in the leaves.

According to results by some reporters $(3$, $4,12,15$, ), the symptom of $\mathrm{NH}_{4}$ injury found on leaves was rolling, and marginal and interveinal chlorosis or necrosis. In this experiment any symptom of $\mathrm{NH}_{4}$ injury was not found on leaves although growth was reduced, and leaves became darker green at higher $\mathrm{NH}_{4}$ ratios. The reason seems to be related to cultivation time. Iwata reported that $\mathrm{NH}_{4}$ injury appears more rapidly on summer crops than winter crops(3). Another study of ours showed that $\mathrm{NH}_{4}$ injury ap- pears on leaves as marginal chlorosis and necrosis in muskmelons grown in early summer, and that $\mathrm{NH}_{4}-\mathrm{N}$ content in leaves is much higher than that in this experiment (11).

$\mathrm{Ca}$ and $\mathrm{Mg}$ in leaves decreased with increasing $\mathrm{NH}_{4}$ ratios (Table 2). These reductions can be explained by the electrochemical equilibrium theory that $\mathrm{NH}_{4}$ uptake must be accompanied by either inorganic anion uptake and/or higher organic anion production, or reduced uptake of inorganic cations(14). As to $\mathrm{Ca}$ nutrition we have pointed out that muskmelons are luxurious consumers of this element(10). Considering this, the decreasing $\mathrm{Ca}$ absorption with higher $\mathrm{NH}_{4}$ ratios is highly correlated with the poor growth of plants.

Nutrient solutions with higher $\mathrm{NH}_{4}$ ratios became extremely acid as the plants extracted $\mathrm{NH}_{4}{ }^{+}$ions from the soil solution (Table 5). This increased acidity seems to be associated with poor utilization of $\mathrm{NH}_{4}, \mathrm{Ca}$ and $\mathrm{Mg}$ which restricted plant growth. Maynard et al. reports that the growth of some vegetable crops is increased by maintaining sand medi$\mathrm{um} \mathrm{pH}$ near neutrality by the addition of $\mathrm{CaCO}_{3}$ regardless of $\mathrm{N}$ source(12). Similar results with muskmelons will be published separately.

\section{Acknowledgement}

Recongnition is given Dr.W. J. Clore for his critical reading of this manuscript.

\section{Literature Cited}

1. Barker, A. V., and D. N. Maynard. 1972. Cation and nitrate accumulation in pea and cucumber plants as influenced by nitrogen nutrition. J. Amer. Soc. Hort. Sci. $100: 27$ 
-30 .

2. Blair, G. J., M.H. Miller, and W. A. MitcHELL. 1970. Nitrate and ammonium as source of nitrogen for corn and their influence on the uptake of other ions. Agron. J. $62: 530$ -532 .

3. Inata, M., and T. Taniuchi. 1953. Influence of the forms of nitrogen supplied on the growth of vegetable crops. J. Japan. Soc. Hort. Sci. 22:183-191. (In Japanese with English summary)

4. Iwata, M. 1958. Influence of the forms of nitrogen supplied on the growth of vegetable crops. II. Effects of varying concentrations of nitrogen in the different forms on the growth of turnip. J. Japan. Soc. Hort. Sci. $27: 21$ -31. (In Japanese with English summary)

5. Iwata, M. 1962. Influence of the forms of nitrogen supplied on the growth of vegetable crops. III. Growth as influenced by variable cations and $\mathrm{pH}$ in the culture solution. J. Japan. Soc. Hort. Sci. 31 : 39-52. (In Japanese with English summary)

6. Iwata, M., and T. Maotani. 1969. Influence of the forms of nitrogen supplied on the growth of vegetable crops. VI. Effects of nitrogen forms on the concentrations of nitrogen fractions and carbohydrates in the plants. J. Japan. Soc. Hort. Sci. $38: 309-317$. (In Japanese with English summary)

7. Kirkby, E. A., and K. Mengel. 1967. Ionic balance in different tissues of the tomato plant in relation to nitrate, urea, or ammonium nitrogen. Plant Physiol. $42: 6-14$.

8. Masui, M., Y. Fukushima, M. Toda, and K. Ezaki. 1960. Studies on the absorption of nutrient elements in muskmelon. II. On nitrogen, potassium, calcium and magnesium levels. J. Japan. Soc. Hort. Sci. 29 : 147-156. (In Japanese with English summary)

9. Masui, M., and K. Anahara. 1967. Studies on the absorption of nutrient elements in muskmelon. X. On the amounts of bed soil as related to kinds of nitrogen fertilizer. Bull. Fac. Agri. Shizuoka Univ. $17: 45-52$. (In Japanese with English summary)

10. Masur, M. 1967. Studies on the fertilization and bed soil management for muskmelon. Technical Bull. Lab. Hort. Fac. Agri. Shizuoka Univ. 2 : 1-90. (In Japanese with English summary)

11. Masui, M., A. Nukaya, A. Ishida, and H. Shigeok A. 1981. Studies on nitrogen nutrition of muskmelons. V. Nitrogen form and $\mathrm{pH}$ in nutrient solution in relation to $\mathrm{Ca}$ addition to sand medium. Abstract. Spring Meeting Japan. Soc. Hort. Sci. 232-233. (In Japanese)

12. MAYNARD, D. N., and A. V. BAKER. 1969. Studies on the tolerance of plants to ammonium nutrition. J. Amer. Soc. Hort. Sci. 94 : 235-239.

13. Peterson, L.A., and G. Chesters. 1964. A reliable total nitrogen determination on plant tissue accumulating nitrate nitrogen. Agron. J. $56: 89-90$.

14. Pill, W.G., V.N. Lambeth, and T.M. HinCKLEY. 1978. Effects of nitrogen form and level on ion concentrations, water stress, and blossom-end rot incidence in tomato. J. Amer. Soc. Hort. Sci. $103: 265-278$.

15. Polizotto, K.R., G.E. Wilcox, and C.M. Jones. 1975. Response of growth and mineral composition of potato to nitrate and ammonium nitrogen. J. Amer. Soc. Hort. Sci. 100 : 165-168. 


\title{
窒素の形態がメロンの生育に及ぼす影響
}

増井正夫・糠谷明・石田明

(静岡大学農学部)

\begin{abstract}
摘 要
窒素 $\left(\mathrm{NO}_{3}\right.$ と $\mathrm{NH}_{4}$ の合計 $)$ 濃度 $90 \mathrm{ppm}$ で, $\mathrm{NO}_{3}$ : $\mathrm{NH}_{4}$ の比率 $10: 0,8: 2,6: 4,5: 5,4: 6,2: 8,0: 10$ の 7 処理を設け, メロンを砂耕栽培した. 全生育期間中 の 1 株当たりの処理溶液は78lであった. $\mathrm{NH}_{4}$ の比率が 高くなると生育は低下し, 果重は減少したが, 果実の糖 度はやや増加した. $\mathrm{NH}_{4}$ の比が増加するにつれ, 葉の $\mathrm{N}$

含量は増加した。植物体各部及び培地 (砂) の $\mathrm{NO}_{3}-\mathrm{N}$ と $\mathrm{NH}_{4}-\mathrm{N}$ 含量は，施用した窒素の形態をよく反映した. 1 株当たりの窒素吸収量は, $\mathrm{NH}_{4}$ のみを施用した区が $5,137 \mathrm{mg}$ で最も多かった。 $\mathrm{NH}_{4}$ の比が増加するにつれ, 土壤溶液中の $\mathrm{NH}_{4}-\mathrm{N}$ 含量は增加したが, $\mathrm{NO}_{3}-\mathrm{N}, \mathrm{Na}$ 含 量, $\mathrm{pH}, \mathrm{EC}$ は減少する傾向がみられた。
\end{abstract}

